\title{
Unemployment and the Real Wage Gap: A Reappraisal of the German Experience
}

By

\author{
Oliver Landmann and Jürgen Jerger
}

Contents: I. Introduction. - II. The Real Wage Gap: Concept and Measurement. - III. A Model of Capital Accumulation, Employment and the Wage Gap. IV. Explaining the Falling Wage Share. - V. Explaining the Slowdown of Capital Formation. - VI. Concluding Remarks. - Data Appendix.

\section{Introduction}

7 The persistence of high unemployment in Europe continues to be a major concern of theoretical and empirical macroeconomics [Drèze and Bean, $1990 \mathrm{~b}$ ]. In particular, the challenge is to explain why both reasonable demand growth and various favourable supply-side developments failed to bring down unemployment decisively in the $1980 \mathrm{~s}$. When unemployment rates first shot up and refused to return to earlier low levels in the 1970s, a consensus on the causes of the problem formed more easily. Adverse supply shocks and explosive wage growth were the essential elements of the mainstream explanation, which heavily relied on two key concepts: the NAIRU, a measure of the unemployment rate consistent with non-accelerating inflation, and the real wage gap, a measure of the amount by which real wages supposedly exceed their equilibrium level. The collision between the soaring wage aspirations of workers and the diminished potential for real income growth pushed up both of these measures [Bruno and Sachs, 1985].

In the 1980s, it became increasingly difficult to explain still higher unemployment rates along the same lines. At first, the blame for the worsening employment picture could be put on the severe demand contraction of 1980-82, which added a layer of Keynesian unemployment to the inherited level of classical unemployment [Bruno, 1986].

Remark: We acknowledge valuable comments on earlier drafts of this paper from participants at the May 1991 IEA conference "Open Economy Macroeconomics" in Vienna and at research seminars at the Universities of Hamburg and Munich. In particular, we thank S. Felder, F.X. Hof and E. Rysavy for pointing out an error in the specification of a preliminary version of our model. 
However, as high unemployment persisted beyond 1982 in the face of recovering demand growth, the Keynesian explanation clearly lost appeal. But so did the classical unemployment hypothesis as real wages grew moderately at rates well below productivity growth year after year.

The coincidence of rising unemployment with what appears to be wage moderation prompts us to take another look at the concept of the real wage gap. Earlier authors such as Schultze [1987] have pointed out that changes in the profit maximizing mix of factor inputs cast doubt on the validity of conventional measures of the real wage gap as an indicator of an excessive real wage level and hence of labour market disequilibrium. In this paper, we take the argument one step further by offering a fully specified dynamic model which endogenizes the choice of factor inputs by firms and thus makes transparent how different shocks affect output, employment, investment, wages and factor shares in different ways. The model pays particular attention to the role that capital accumulation has to play in an explanation of labour market developments, thus taking up a theme emphasized by Fitoussi and Phelps [1988] in their account of the European unemployment conundrum.

The empirical sections of our paper look at the experience of Germany, confronting the predictions of the model with the most salient features of macroeconomic performance since 1970. The key relationships of the model are estimated with German data for the period $1961-91$. The main indicators that will concern us in the subsequent analysis are compiled in Table 1 and Figure 1. The figure charts the evolution of our own measure of the real wage gap (as estimated below) along with the unemployment rate. Evidently, the two variables moved in opposite directions for the most part of the 1980s. The table summarizes some other distinct trends: the slowdown in the average growth of labour productivity and real wages, the slowdown in the pace of capital accumulation as reflected both in the growth rate of the capital stock and in the investment ratio, and the marked rise of the real interest rate after $1980 .^{1}$

We now proceed as follows: In Section II, we discuss some conceptual issues relating to the real wage gap and present our own estimate.

\footnotetext{
1 The strong demand-led boom that the West German economy experienced in 1990-91 due to the unification generated a (temporary?) pick-up of real wage growth, employment growth and investment. However, the 1980-91 averages of these variables do not differ very much from their 1980-89 averages, in particular as they are compared with their pre-1980 values.
} 
Figure 1 - The Wage Gap (left scale) and the Unemployment Rate (right scale) in Germany, 1961-1991

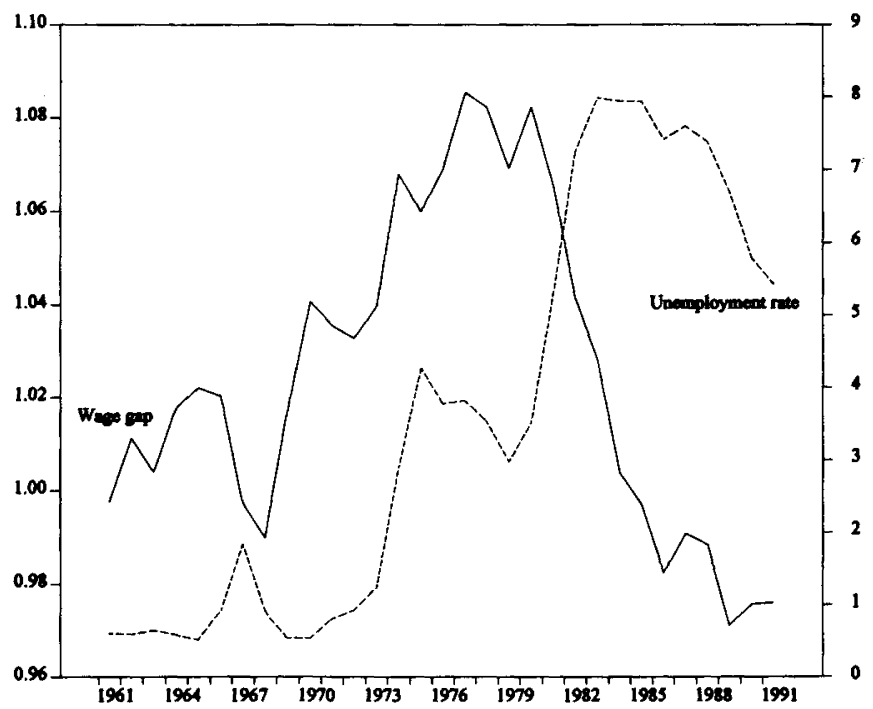

Table 1 - Selected Economic Indicators for Germany, 1961-91

\begin{tabular}{|c|c|c|c|}
\hline Variable & $1961-1973$ & 1974-1979 & $1980-1991$ \\
\hline Unemployment rate ${ }^{2}$ & 0.8 & 3.5 & 6.6 \\
\hline GNP per hour worked ${ }^{b}$ & 5.1 & 3.6 & 2.0 \\
\hline Real wages per hour ${ }^{b}$ & 5.2 & 2.9 & 1.6 \\
\hline Capital stock ${ }^{b}$ & 5.6 & 3.6 & 2.8 \\
\hline \multicolumn{4}{|l|}{ Net investment } \\
\hline aggregate economy ${ }^{\mathfrak{c}}$ & 21.4 & 13.5 & 10.2 \\
\hline private sector $^{c}$ & 16.6 & 9.5 & 7.8 \\
\hline Real interest rate ${ }^{d}$ & 2.8 & 3.2 & 4.6 \\
\hline
\end{tabular}

Source: See data appendix.

Our model is introduced in Section III. Section IV empirically investigates the implications of the model for the time path of the labour share and the real wage gap. Section V is concerned with the slowdown of capital formation. Section VI concludes. 


\section{The Real Wage Gap: Concept and Measurement}

The concept of the real wage gap is intended to indicate the amount by which the prevailing real wage exceeds the level consistent with full employment. The standard procedure to construct such an indicator is to choose a base period in which the economy was near full employment and for which the real wage gap is set equal to a benchmark value. Next, the hypothetical rate of real wage growth that would have been feasible at continuous full employment is estimated and compared with the rate actually observed [see e.g. Sachs, 1983; Bruno and Sachs, 1985]. The "feasible" growth rate of real wages obviously depends on the pace of an economy's productivity advance. However, it has soon been realized that the actual growth rate of labour productivity is a poor proxy for the feasible growth rate of real wages if unemployment is not constant. The reason is that labour productivity endogenously responds to real wage changes as firms move along their labour demand schedules. Depending on the elasticity of labour demand, any excess real wage growth will appear at least in part to "pay for itself".

The point can be seen by considering a CES representation of the production process which relates output $Y$ to the capital stock $K$, labour input $N$ and time $t$ :

$$
\begin{aligned}
Y=F(K, N, t)=A[ & b\left\{N_{t} \exp (\lambda t)\right\}^{-e} \\
& \left.+(1-b)\left\{K_{t} \exp (\mu t)\right\}^{-\ell}\right]^{-1 / e} .
\end{aligned}
$$

The parameters $\lambda$ and $\mu$ denote labour augmenting and capital augmenting technical progress, respectively. For reasons that will become clear below, the specification of technical progress is sufficiently general to leave open the possibility of non-neutral progress. ${ }^{2}$ With competitive firms, the real wage $W$ must equal the marginal product of labour: ${ }^{3}$

$$
W=b A^{-e} \exp (-\varrho \lambda t)(Y / N)^{1+e} .
$$

Solving for the log of the average product of labour (and denoting logs by lower-case letters), we get

$$
y-n=\alpha_{0}+\sigma(w-\lambda t)+\lambda t .
$$

2 The wage gap literature typically assumes Hicks-neutrality [see e.g. Schultze, 1987]. This corresponds to the special case $\lambda=\mu$ in our formulation.

3 Allowing for monopolistic deviations from the benchmark case of perfect competition would add a constant term (related to the price elasticity of demand). Since none of our results depends on variations in the degree of monopoly power, we ignore this factor throughout. 
This equation relates labour productivity to the real wage and to labour-augmenting technical progress $\left(\alpha_{0}\right.$ is a constant; $\sigma$ is the elasticity of substitution, defined by $\left.(1+\varrho)^{-1}\right)$. More precisely, labour productivity grows at the trend rate $\lambda$ as long as the real wage grows at the same rate. If real wage growth deviates from this trend rate, productivity growth deviates in the same direction depending on the elasticity of substitution. In the limiting case of the Cobb-Douglas production function $(\sigma=1)$, productivity moves one-to-one with the real wage so that any real wage growth appears "justified" ex post by the resulting productivity increase. ${ }^{4}$ The trend deviation of the real wage, $w-\lambda t$, is what Gordon [1988, p. 287] has called the "adjusted wage gap". By relating the real wage to trend productivity rather than actual productivity, this measure is presumed free of any bias stemming from endogenous productivity changes. We can rewrite (3) so as to make plain how the adjusted wage gap is related to the unadjusted wage gap, where the latter is simply (an index of) the wage share in national income:

$$
w+n-y=-\alpha_{0}+(1-\sigma)(w-\lambda t) .
$$

In order to calculate the adjusted wage gap, we estimate (3) and (4) using quarterly data from the period 1961:1 to 1991:4. The equations are estimated in level form and the time series involved are tested for the property of cointegration. This test indicates whether the long-run "equilibrium" relationship between output, employment and the real wage, which is implied by the optimizing behaviour of firms, is supported by the data. ${ }^{5}$

Cointegration is only defined for variables of the same order of integration. Therefore, it is necessary to determine the order of integration of the time series before cointegration diagnostics are used for the regressions. We employ the methods suggested by Sargan and Bhargava [1983], Phillips [1987], Phillips and Perron [1988] and Stock and Watson [1988]. The first one is based on the Durbin-Watson statistic (SBDW), the second is a modification of the augmented Dickey-Fuller $[1979,1981]$ test and includes a constant, a time trend and 4 lags of the differenced variable (DF/PP(4)). Finally, the Stock-Watson test also

\footnotetext{
4 This observation has been put forward as a principal objection against productivityrelated wage guidelines; see Hellwig and Neumann [1987].

5 See Engle and Granger [1987] for an exposition of the methodology. The presence of cointegration also justifies more confidence in the quality of estimates involving nonstationary variables than traditional econometric theory would imply [Stock, 1987].
} 
Table 2 - Integration Diagnostics

\begin{tabular}{|l|lc|cc|cc|}
\hline \multirow{2}{*}{ Variable } & \multicolumn{2}{|c|}{ SBDW } & \multicolumn{2}{c|}{ DF/PP(4) } & \multicolumn{2}{c|}{ StWa } \\
\cline { 2 - 8 } & level & $\Delta$ level & level & $\Delta$ level & level & $\Delta$ level \\
\hline$(W \cdot N) / Y$ & 0.183 & $2.407^{* * *}$ & -2.475 & $-14.077^{* * *}$ & -7.509 & $-175.87^{* * *}$ \\
$w+n-y$ & 0.185 & $2.409^{* * *}$ & -2.493 & $-14.125^{* * *}$ & -7.531 & $-149.06^{* * *}$ \\
$w$ & 0.002 & $1.914^{* * *}$ & -1.122 & $-12.960^{* * *}$ & -1.102 & $-141.33^{* * *}$ \\
$k-n$ & 0.002 & $2.436^{* * *}$ & -0.136 & $-17.306^{* * *}$ & -0.665 & $-158.69^{* * *}$ \\
$y-n$ & 0.002 & $2.451^{* * *}$ & -1.116 & $-15.952^{* * *}$ & -1.301 & $-155.39^{* * *}$ \\
$* * *$ \\
The null is rejected at the significance level $<1$ per cent. For the data see the \\
Appendix.
\end{tabular}

includes the intercept and a trend, thus the $\boldsymbol{q}_{f}^{\tau}$-test (in the symbols of Stock and Watson [1988]) is used (StWa).

The procedures test the null "random walk" (with drift and trend) against the alternative hypothesis of a stationary process. The results for levels and first differences are presented in Table $2 .^{6}$ It is evident that all time series to be used are integrated of the order one.

For the purpose of estimation, (3) and (4) are written as follows:

$$
\begin{aligned}
& y-n=a_{0}+a_{1} w+a_{2} t+a_{3} \tau+\zeta\left(y-y^{*}\right) \\
& w+n-y=b_{0}+b_{1} w+b_{2} t+b_{3} \tau+\zeta\left(y-y^{*}\right) .
\end{aligned}
$$

With $y^{*}$ denoting the log of potential real GNP, $\left(y-y^{*}\right)$ captures the cyclical sensitivity of productivity and the wage share. ${ }^{7}$ Both regressions have been run with and without this cyclical adjustment (columns 2 and 1 in Table 3, respectively). Technical progress is assumed to be exogenous and is captured by trend terms in the usual manner. $t$ denotes a time trend for the whole sample, whereas $\tau$ is set equal to zero from 1961:1 through 1973:4 and increases by one unit per quarter thereafter. Thus, the equations allow for a break in the rate of trend productivity growth after 1973 . The rates are denoted by $\lambda_{1}(1961-$ 1973) and $\lambda_{2}$ (1974-1991), respectively.

\footnotetext{
6 Besides the wage, the wage share and the average product of labour which appear in logs in (3) and (4), Table 2 also displays the integration diagnostics for some variables which will be used below.

7 Potential output was calculated from our database (see Appendix) along the lines proposed by the Sachverständigenrat [1992, p. 259].
} 
Table 3 - Estimates of $\left(3^{\prime}\right)$ and $\left(4^{\prime}\right)$

\begin{tabular}{|c|c|c|c|c|}
\hline & & & & \\
\hline & & Depe & ariable & \\
\hline & & & & \\
\hline & (1) & (2) & (1) & (2) \\
\hline$\alpha_{0}$ & -0.014 & -0.016 & -0.020 & -0.023 \\
\hline$\sigma$ & 0.438 & 0.370 & 0.305 & 0.181 \\
\hline$\lambda_{1}$ & 0.013 & 0.013 & 0.012 & 0.012 \\
\hline$\lambda_{2}$ & 0.007 & 0.007 & 0.006 & 0.006 \\
\hline & & 0.273 & & 0.501 \\
\hline $\mathbf{R}^{2}$ & 0.998 & 0.998 & 0.650 & 0.832 \\
\hline DW & $0.737^{* * *}$ & 0.860 & $0.510^{* * *}$ & 0.677 \\
\hline & $-5.253^{* * *}$ & & $-4.193^{* * *}$ & \\
\hline ADF (4) & $-3.231^{* *}$ & & $-3.356^{* *}$ & \\
\hline $\begin{array}{l}\text { Note: } \\
\tau .-\mathrm{t} \text {-st } \\
\text { tion in } \\
\text { variabl } \\
\text { see the }\end{array}$ & $\begin{array}{l}\text { are report } \\
\text { lot reporter } \\
\text { ith non-sta } \\
\text { grated at t }\end{array}$ & $\begin{array}{l}\text { implied b } \\
\text { ause they } \\
\text { ry variab } \\
\text { and } 5 \text { per }\end{array}$ & $\begin{array}{l}\text { timated coeff } \\
\text { converge to a } \\
\text { Phillips, } 198 \\
\text { el, respective }\end{array}$ & $\begin{array}{l}\text { ts of } w, t \text { a } \\
\text { ting distrib } \\
{ }_{* * *}^{* *}, \mathrm{~T} \\
\text { For the da }\end{array}$ \\
\hline
\end{tabular}

The estimated coefficients translate into the technical parameters of (3) according to

$$
\alpha_{0}=a_{0} \quad \sigma=a_{1} \quad \lambda_{1}=a_{2} /\left(1-a_{1}\right) \quad \lambda_{2}=\left(a_{2}+a_{3}\right) /\left(1-a_{1}\right)
$$

and of (4) according to

$$
\alpha_{0}=-b_{0} \quad \sigma=1-b_{1} \quad \lambda_{1}=-b_{2} / b_{1} \quad \lambda_{2}=-\left(b_{2}+b_{3}\right) / b_{1} .
$$

The cointegration diagnosis is based on the Durbin-Watson coefficient (SBDW), the (simple) Dickey-Fuller test (DF) and the augmented Dickey-Fuller test $(\operatorname{ADF}(4)){ }^{8}$ The results are summarized in Table 3.

Noting that the parameters are reasonably stable across specifications, we can draw the following conclusions from these estimates:

8 Our application of the cointegration technique is somewhat peculiar in that the equations include deterministic trend terms. The trend term, suggested by theory to capture the effects of technical progress, is, of course, non-stochastic, and thus falls outside the concept of integratedness. Nevertheless, cointegration can still be interpreted as indicating the stationarity of the residual error and thus serves us as a means of regression diagnostics. The property of cointegration in this case is defined between the deterministic-trend-corrected LHS and the remaining RHS variables. 
(a) In line with most previous work, we find an elasticity of substitution well below unity. ${ }^{9}$ By implication, the adjusted wage gap generally moves in the same direction as the plain wage share.

(b) The cyclical proxy enters the equations with the expected sign, reflecting the pro-cyclical behaviour of productivity and the corresponding counter-cyclical behaviour of the wage share.

(c) The significant difference between $\lambda_{1}$ and $\lambda_{2}$ reflects the wellknown slowdown of trend productivity growth in the mid-1970s. Experimentation with another dummy for the 1980-91 period was unsuccessful (confirming a similar result obtained by Gordon [1988]). This suggests that the noticeable slowdown of actual productivity growth in the 1980s as compared with the 1970s should not be interpreted as another structural break, but as an endogenous response to some force which simultaneously depressed real wage growth. As we will argue below, this force was the slowdown of capital deepening. ${ }^{10}$

(d) The cointegration diagnostics indicate the presence of cointegration for both equations ${ }^{11}$ and thus justify some confidence in the existence of a long-term relation linking output, employment and the real wage. In this sense, the data do not refute the notion that firms operate on their neoclassical labour-demand schedules in the long run.

To calculate the adjusted wage gap index, we subtract the estimated trend productivity term $\left[\lambda_{1} t+\left(\lambda_{2}-\lambda_{1}\right) \tau\right]$ from the (log of the) actual real wage $w$. The series plotted in the top panel of Figure 1 is based on an annual growth rate of trend productivity amounting to 4.8 per cent from 1961 to 1973 and 2.4 per cent from 1974 to 1991 , as implied by the regression results for equation (4') in Table 3. Evidently, the wage gap rose substantially in the years after 1969, reflecting the abrupt acceleration of real wage growth (the "wage explosion") in that period. From 1977 to 1991, in contrast, the real wage level increased at only about half the rate of trend productivity growth, thus driving down the wage gap index well below unity (the 1961 benchmark).

9 Our estimated $\sigma$ is particularly close to McCallum's [1985, p. 446]. Entorf et al. [1990] estimate a value of 0.3 using the same technology specification with annual data from 1970-1986 for the private sector in Germany.

10 According to our derivation of (3), and contrary to Gordon's [1988, p. 286] presumption, $\lambda$ does not pick up changes in the capital-labour ratio.

${ }_{11}$ Cointegration tests apply only to regressions without $\left(y-y^{*}\right)$. The cyclical proxy is stationary by construction, so cointegration in the equations which include this term is ill-defined. 


\section{A Model of Capital Accumulation, Employment and the Wage Gap ${ }^{12}$}

Our next task is to develop a theoretical framework which allows us to explain variations in the level of the real wage gap and to relate them to changes in other macroeconomic variables. In particular, we wish to show how a sustained rise in unemployment can be associated either with an increasing real wage gap (as in the 1970s) or with a decreasing real wage gap (the experience of the 1980s). Our model abstracts from monetary and other demand-side disturbances that shape the cyclical behaviour of the economy. The focus is entirely on the longer-term interaction of unemployment, the wage gap, wage setting behaviour and capital formation. To simplify the exposition, the theoretical analysis in this section also assumes away autonomous productivity change due to technical progress. In terms of the notation introduced in the last section, this amounts to $\lambda=\mu=0$ so that the adjusted real wage gap index can be identified with the real wage itself. Another implication of this simplifying assumption is that the capital stock and the capital-labour ratio are stationary in equilibrium. ${ }^{13}$ Firms are assumed to face an exogenous real world interest rate and to operate on competitive product markets. ${ }^{14}$ They choose their labour input as well as their real investment spending over time so as to maximize the present value of cash flows $V_{0}$ :

$$
V_{0}=\int_{0}^{\infty}\left[F\left(K_{t}, N_{t}\right)-W_{t} N_{t}-c\left(\Phi_{t}\right) K_{t}\right] \exp (-R t) \mathrm{d} t
$$

subject to

$$
\dot{K}_{t} \equiv \mathrm{d} K_{t} / \mathrm{d} t=K_{t}\left(\Phi_{t}-\delta\right),
$$

where
$K$ : Capital stock
$W$ : Real wage
$\Phi \equiv I / K$
$R$ : Real interest rate
$N$ : Labour input
c: Installation cost of capital goods
I: Real investment spending (gross)
$\delta$ : Proportional rate of depreciation.

A dot over a variable denotes its derivative with respect to time. $F$ is assumed to be a well-behaved constant returns to scale produc-

12 The model of this section is very similar in spirit to the one in Burda [1988].

13 Alternatively, changes in these variables should be interpreted as changes relative to the respective trend paths.

${ }^{14}$ Nothing of substance would change if we allowed for some price-setting power on the part of firms. 
tion function. Following standard investment theory [e.g. Blanchard and Fischer, 1989, p. 58], we assume a convex cost function for the installation of capital goods, i.e. $c^{\prime}>0, c^{\prime \prime}>0$. The behavioural implications of this optimization problem can be derived in the usual way by setting up the current value Hamiltonian $H$ and establishing the firstorder conditions: ${ }^{15}$

$$
\begin{aligned}
& H=F(K, N)-W N-c(\Phi) K+q K(\Phi-\delta) \\
& \partial H / \partial N=F_{2}(K, N)-W=0 \\
& \partial H / \partial I=-c^{\prime}(\Phi)+q=0 \\
& \partial H / \partial K=F_{1}(K, N)-c(\Phi)+q(\Phi-\delta)=R q-\dot{q},
\end{aligned}
$$

where

q: Costate variable (shadow price of capital)

$F_{i}$ : Partial derivative of $F$ with respect to the $i$-th argument.

The optimality condition (8) corresponds to equation (2) above. It implicitly shows labour demand as a function of the capital stock and the real wage. Equations (6), (9) and (10) together determine the dynamics of capital accumulation along the lines of Tobin's $q$ theory of investment. Instead of the usual $(q, K)$-format, we choose here a $(\Phi, K)$ representation to make the time path of investment more readily visible. Substituting equation (9) and its time derivative into equation (10), we get

$$
\dot{\Phi}=\frac{1}{c^{\prime \prime}}\left[c^{\prime}(R+\delta-\Phi)+c(\Phi)-F_{1}(K, N)\right] .
$$

We cannot analyze the dynamics of the system formed by (6) and (11) without taking into account the interdependence of capital formation and the labour market. The marginal productivity of capital $F_{1}$ depends on labour input $N\left(F_{12}>0\right)$. Employment, in turn, is determined on the labour market where the labour demand of firms as implied by (8) depends on the size of the capital stock. To complete the description of the labour market, we assume wage-setting to be governed by an equation of the following form:

where

$$
W=\psi\left(N / N^{*}, z\right), \quad \psi_{1}, \psi_{2}>0
$$

$N^{*}$ : Labour force (exogenous)

$z$ : Vector of exogenous variables relevant to wage-setting.

15 Hereafter, time subscripts will be dropped where dispensable. 
We do not provide microeconomic foundations for this relationship, but we note that it is consistent with a number of labour market models such as monopoly union models, bargaining models, efficiency wage models or insider-outsider models (see also the discussion in Lindbeck [1992]). Besides the unemployment rate, these models suggest various other variables that may affect wage-setting. Obvious examples are total factor productivity, unemployment benefits, the terms of trade, taxes and union militancy. Such variables are captured by the exogenous vector $z$.

Equations (8) and (12) together determine the equilibrium levels of employment and the real wage. Solving for $N$ and $W$ we get

$$
\begin{array}{ll}
N=g\left(K, N^{*}, z\right) & g_{1}, g_{2}>0, g_{3}<0 \\
W=h\left(K, N^{*}, z\right) & h_{1}, h_{3}>0, h_{2}<0 .
\end{array}
$$

This is an equilibrium in the sense that the real wage outcome intended by wage-setters according to (12) is consistent with the demand price of labour derived from (8). Since the wage bargain is cast in nominal terms, actual outcomes may differ from the equilibrium solution due to expectational errors and nominal rigidities [Blanchard, 1990]. Any such disequilibrium sets in motion an accelerating wageprice spiral which can go on as long as authorities are prepared to provide the necessary monetary accommodation. As soon as nominal demand growth is adjusted, however, so as to end the wage-price spiral, output and employment are eventually forced back to their equilibrium levels [Layard and Bean, 1989]. Since the present paper is not concerned with these transitory monetary disequilibria, any subsequent reference to employment in this section is to equilibrium employment as determined by (13). The corresponding unemployment rate $\left(N^{*}-g\right) / N^{*}$ is what Lindbeck [1992] has termed the QERU ("quasi-equilibrium rate of unemployment") or what in a Phillipscurve context would be referred to as the NAIRU.

After substituting (13) into (11), which gives

$$
\dot{\Phi}=\frac{1}{c^{\prime \prime}}\left[c^{\prime}(R+\delta-\Phi)+c(\Phi)-F_{1}\left\{K, g\left(K, N^{*}, z\right)\right\}\right],
$$

we can proceed to the analysis of the joint dynamics of capital accumulation and employment. Figure 2 displays the relevant phase diagram. The $\dot{K}=0$ locus depicts the equilibrium condition for the capital stock derived from the state equation (6). It is vertical at $\Phi=\delta$. The $\dot{\Phi}=0$ locus is the condition for the investment-capital ratio to remain 
Figure 2 - The Laws of Motion for Investment and the Capital Stock

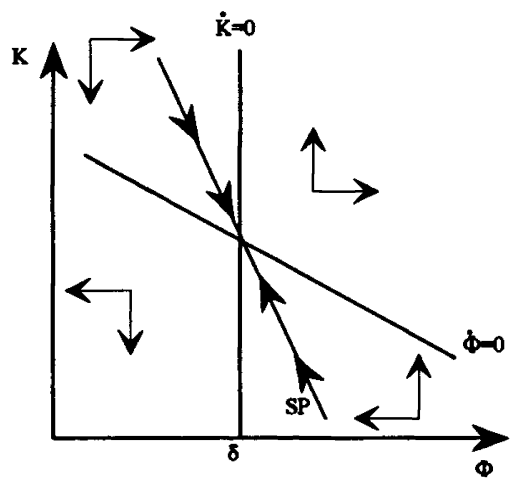

stable. To determine its slope, we set $\dot{\Phi}=0$ in $\left(11^{\prime}\right)$ and totally differentiate with respect to $K$ and $\Phi$. With the normalization $N^{*}=1$, the equations (8), (12) and (13) imply $g_{1}=F_{21} /\left(\psi_{1}-F_{22}\right)$ so that the slope is given by

$$
\left.\frac{\mathrm{d} K}{\mathrm{~d} \Phi}\right|_{\dot{\Phi}=0}=\frac{c^{\prime \prime}(R+\delta-\Phi)\left(\psi_{1}-F_{22}\right)}{F_{11}\left(\psi_{1}-F_{22}\right)+F_{12} F_{21}} .
$$

With constant returns to scale, the denominator of $(15)$ is negative as long as $\psi_{1}>0$. The numerator is positive if the real interest rate is positive (which we assume) and if the system is close enough to its equilibrium point where $\Phi=\delta$. Thus, the $\dot{\Phi}=0$ locus is depicted as downward sloping. ${ }^{16}$ The direction of the arrows of motion can be derived from (6) and $\left(11^{\prime}\right)$ in the usual way. The overall equilibrium of the system is obviously a saddlepoint. SP is the unique stable path leading to this equilibrium. The transversality condition

$$
\lim _{t \rightarrow \infty} q_{t} \exp (-R t)=0
$$

ensures that the system always converges to its equilibrium along this stable path.

\section{A Domestic Wage Shock}

We are now in a position to analyze the dynamic consequences of exogenous shocks. The wage explosion of the early 1970s can be

16 In the limiting case of $\psi_{1}=0$, i.e. complete real wage rigidity, the $\dot{\phi}=0$ locus is vertical and no equilibrium exists. In Figure 2 , the $\Phi=0$ locus is drawn as a straight line and thus must be interpreted as a linear approximation of (15) around the steady state. 
Figure 3-A Sequence of a Wage Shock and an Interest Rate Shock: The Response of Investment, the Capital Stock, the Real Wage and Employment
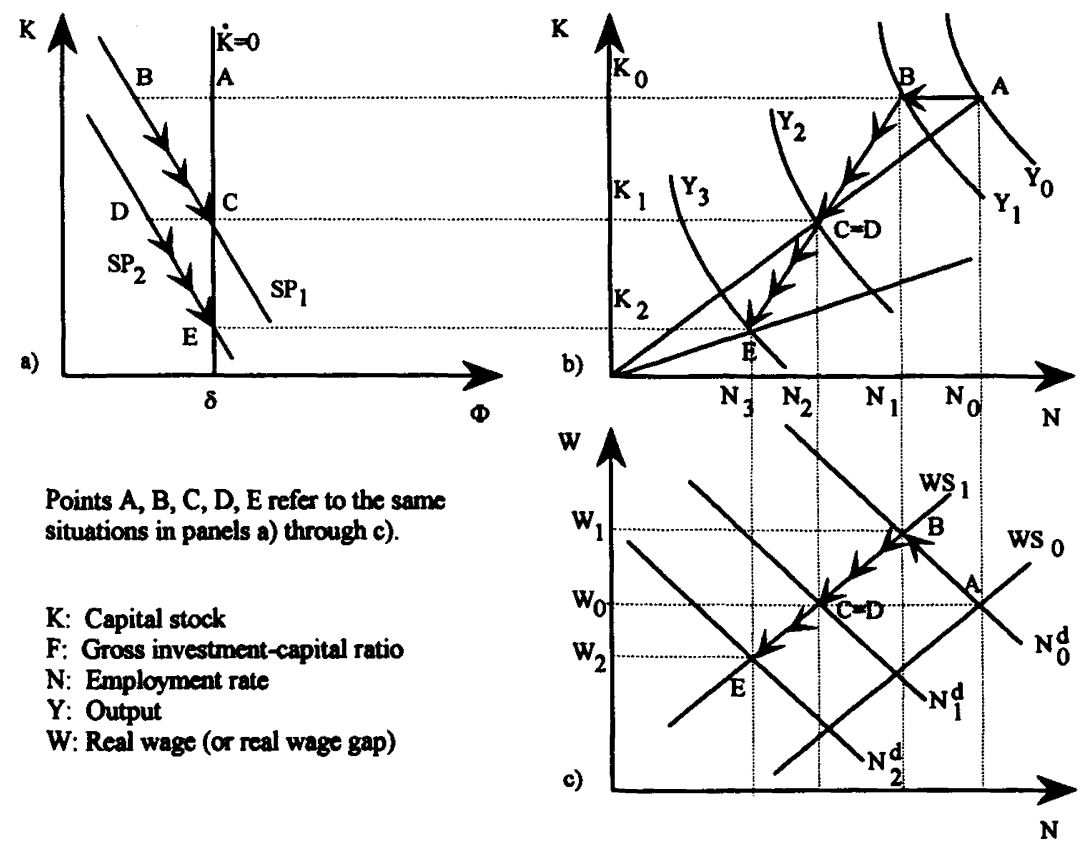

Points A, B, C, D, E refer to the same situations in panels a) through $\mathrm{C}$ ).

$\mathrm{K}$ : Capital stock

F: Gross investment-capital ratio

N: Employment rate

Y: Output

W: Real wage (or real wage gap)

represented, in terms of our model, as an abrupt increase in $z$. Inspecting $\left(11^{\prime}\right)$ - and taking account of $F_{12} g_{3}<0$ - we can see that this shock displaces the $\dot{\Phi}=0$ locus downward. In panel a) of Figure 3, point $A$ represents the initial equilibrium position of the system. The downward shift of the $\dot{\Phi}=0$ locus (which is not depicted) is assumed to give rise to a new long-run equilibrium at point $\mathrm{C}$ with a lower capital stock. Since the capital stock is predetermined at each point of time, the new equilibrium cannot be reached immediately. Rather, the impact effect of the shock is to reduce investment sharply so as to place the system on the stable path $\mathrm{SP}_{1}$ (point B). Over time, the capital stock gradually adjusts downward while investment recovers so far as to reestablish the initial level of $\Phi$ at the new equilibrium point $C$.

To make clear what is going on behind the scenes of this adjustment process, we have attached two further panels to Figure 3. Panel c) depicts the interaction of labour demand and wage-setting behaviour as described by (8) and (12). Again, point A is the initial equilib- 
rium. As the push for higher wages sets in, the wage-setting schedule shifts up from WS $\mathrm{WS}_{0}$ to $\mathrm{WS}_{1}$. Given the inherited capital stock $K_{0}$, the real wage rises to $W_{1}$. Employment must fall to $N_{1}$ if the wage-price spiral resulting from the wage shock is to be contained. This is not the end of the adjustment process, however. Since the marginal productivity of labour depends on the size of the capital stock, the labour demand curve gradually shifts to the left as the disinvestment process is taking its course. As a consequence, employment is further depressed to $\mathrm{N}_{2}$ while at the same time the initial real wage gain is completely eroded. It may appear paradoxical that the long-run effect of the drive for higher real wages is to leave the real wage level unaffected. But that is what the constant returns to scale technology and the endogenous capital stock imply. As Blanchard [1990, pp. 75-76] has put it, the long-run labour demand curve is horizontal [see also Bean, 1989].

The implied co-movement of the capital stock and employment - and hence the capital-labour ratio - is illustrated in panel b). After an initial rise in the capital-labour ratio due to the loss of employment between points $\mathrm{A}$ and $\mathrm{B}, \mathrm{a}$ mutually reinforcing contraction of capital and labour input leads to a new equilibrium at point $C$ where the original intensity is again supported by the original factor price ratio. ${ }^{17}$

The model tells a story which is roughly in line with the facts presented in the introduction. The pattern of simultaneously rising unemployment and real wages depicted by the transition from point $A$ to point $B$ in panel c) of Figure 3 mirrors the German experience and, for that matter, the experience of many other European countries - in the first half of the 1970s when the NAIRU by most accounts rose from around 1 per cent to around 4 per cent [see e.g. Franz, 1987]. This was the period that revived the interest in the notion of classical unemployment and led to the construction of wage gap indices. Of course, the exact timing of actual output and employment developments was strongly influenced by the monetary disturbances which supervened on the real forces analyzed above. Whereas the increased wage pressure dates back to the late $1960 \mathrm{~s}$, it was at first deflected into rising inflation rates by a highly accommodating stance of nominal demand management. Therefore, the plunge of investment was delayed and actual unemployment did not catch up with the rising

17 Note again that the model portrays a stationary economy. All the results carry over to a growing economy, however, if the variables are reinterpreted as trend-adjusted (see Section IV for such a reinterpretation). 
NAIRU until 1974/75 when the monetary accommodation of inflation was discontinued.

The wage gap began to decline in the second half of the 1970s. However, employment growth still fell short of its pre-recession rate and unemployment remained stubbornly high. Investment remained depressed. The failure of a falling wage gap to bring down unemployment is not surprising in view of the properties of the transition path from point $B$ to point $C$ in Figure 3. There is no simple and stable relationship between real wage and unemployment once the endogenous adjustment of the capital stock is taken into account.

\section{A Foreign Interest Rate Shock}

To portray the situation of the early 1980 s as a case of a pure real interest rate shock is clearly an oversimplification. In particular, the rise in world interest rates coincided with the second oil price shock and with a sharp appreciation of the U.S. dollar. Germany, along with most other European countries, thus experienced a deterioration of its terms of trade which by itself contributed to inflationary pressure and to a further increase in the NAIRU. However, because this disturbance was not as pronounced as the wage shock of the early 1970s, and also because it was subsequently reversed, we neglect it in the following analysis and instead focus on the consequences of the more sustained increase in the real rate of interest.

We turn again to Figure 3 and consider an initial equilibrium depicted by point $\mathrm{C}$ in each of the three panels (thus assuming, for the sake of simplicity, that all variables, including the capital stock, have completed their adjustment to the previous shock). A rise in the real interest rate lowers the equilibrium capital stock. In the $(\Phi, K)$ phase diagram, the $\dot{\Phi}=0$ locus thus shifts down once more as can be verified from equation $\left(11^{\prime}\right)$. The long-run equilibrium position of the system moves further down along the $\dot{K}=0$ locus to point $E$ in panel a) of Figure 3. This equilibrium can only be reached along the new stable path $\mathrm{SP}_{2}$. Investment must fall on impact so as to place the system on this path at point $D$. The capital stock thus gradually adjusts downward to its new optimal level $K_{2}$.

As far as capital formation is concerned, the real interest rate shock evidently generates the same type of dynamic response as the wage shock. The labour market response, in contrast, is different. Since the interest rate does not directly enter the wage-setting equation or the labour demand equation in this model, neither the natural employ- 
ment rate nor the wage rate are affected on impact. As the capital stock adjusts over time, however, labour demand falls. This is represented by the displacement of the $N^{d}$ schedule from $N_{1}^{d}$ to $N_{2}^{d}$ in panel c) of Figure 3. As a result, the real wage and employment continue to decrease together along the wage-setting curve $\mathrm{WS}_{1}$, from point $\mathrm{D}(=\mathrm{C})$ to point E. Panel b) again illustrates the co-movement of the capital stock, employment and output. While both factor inputs fall in the course of the adjustment process, the capital-labour ratio must also decline in response to the increased cost of capital and the falling real wage. Therefore, the new equilibrium point $E$ is located on a lower ray from the origin than the previous equilibrium $C$ in panel $b$ ).

The theoretical analysis of the interest rate increase again yields predictions that appear to be broadly in line with the facts. The investment weakness predicted by the model is one of the most salient features of Germany's macroeconomic performance during the 1980s. Throughout the decade, the net investment ratio never recovered from the trough of the 1981/82 recession to anywhere near the already depressed level of the 1970s. Of course, the capital-labour ratio did not literally fall as it does in our stationary-model economy. But its rate of growth fell to a post-war low which was widely seen as a major cause of the continued slowdown of labour productivity growth. Discussing the consequences of this investment slowdown, the OECD [1988, p. 53] aptly diagnosed a "vicious circle" of sluggish capacity growth and job creation in which "weak economic growth eventually began feeding upon itself". The mutually depressing effects of falling output and employment on investment and of inadequate capital formation on the demand for labour are indeed at the very core of the contractionary adjustment process portrayed in Figure 3.

Due to our normalization of the total labour force $\left(N^{*}=1\right)$, the fall in $N$ is to be interpreted as a fall in the employment rate, not necessarily in the absolute volume of employment. As a matter of fact, employment growth picked up somewhat after 1983, but not enough to keep up with the expanding supply of labour. ${ }^{18}$ The coincidence of a sharply falling wage gap and an increasing unemployment rate which has done so much to discredit the classical-unemployment hypothesis and the traditional wage-gap analysis in the $1980 \mathrm{~s}$ is a

18 The effects of the rise in the labour force are ignored in this paper; see, however, the discussion in Landmann and Jerger [1993]. 
straightforward property of the transition from point $D$ to point $E$ in panel c) of Figure 3. Again, the time path of actual unemployment differed from the gradual upward-creep which the model predicts for the NAIRU. The actual unemployment rate shot up in 1981-83 under the influence of a stern anti-inflationary monetary policy and was kept high for an extended period of disinflation during which most estimates of the NAIRU were gradually revised upwards [Franz, 1987]. While this behaviour of the NAIRU may give the appearance of hysteresis, it is also consistent with the disinvestment mechanism described above. Of course, the actual empirical importance of this mechanism cannot be established by a rough comparison of an abstract model with the stylized facts. In the next section, we therefore take a first step towards a more formal empirical underpinning of our story.

\section{Explaining the Falling Wage Share}

The above analysis suggests that the concept of the (adjusted or unadjusted) real wage gap is of little use in spotting a real wage problem on the labour market. In fact, the very notion of an "excessive real wage level" is ill-defined in view of the endogenous determination of the real wage. Many writers have emphasized that the CES technology (for $\sigma \neq 1$ ) actually predicts such changes in distributional shares as a consequence of changes in the factor-price ratio and the capitallabour ratio even if full employment is permanently maintained [e.g. McCallum, 1985; Krugman, 1987; Schultze, 1987]. As Gordon [1988, p. 285] has put it: "With an elasticity of substitution between labour and capital below unity, the normal process of capital accumulation would be expected gradually to raise labour's share and measured wage gap indexes." But as a matter of fact, the capital-labour ratio continued to rise throughout the past decade in the face of a substantial decline of the adjusted wage gap. Since the endogenous adjustment of the capital stock plays a central part in our model of wage and unemployment dynamics, we now take up the question whether the observed time path of the wage gap and the labour share can be explained by the changing pattern of capital accumulation and employment growth as our theoretical analysis implies.

A good starting point for the empirical analysis is the quadratic approximation of the CES function (1), first proposed by Kmenta [1967]. With a specification of technical progress as in (1), this logarith- 
mic approximation is

$$
\begin{aligned}
y= & a+[b \lambda+(1-b) \mu] t+b n+(1-b) k \\
& -\frac{1}{2} \varrho b(1-b)[k-n-(\lambda-\mu) t]^{2} .
\end{aligned}
$$

Here again, $y, k$ and $n$ denote the log, respectively, of real output, the capital stock and employment. The parameters have the same meaning as in (1) above.

If labour receives its marginal product, the labour share is equal to the partial elasticity of output with respect to labour:

$$
\frac{\partial y}{\partial n}=W \cdot N / Y=b+\varrho b(1-b)[k-n-(\lambda-\mu) t] .
$$

Two points emerge from (17). First, an increase in the capitallabour ratio raises the labour share at any given time if the elasticity of substitution is below unity $(\Leftrightarrow \varrho>0)$ as our estimates in Section II suggest it is. Second, the time path of the labour share is not uniquely determined by the capital-labour ratio, but also depends on the pace and the nature of technical progress. Only in the special case of Hicksneutral progress $(\lambda=\mu)$ would an ongoing process of capital deepening inevitably result in the ever-increasing labour share expected by Gordon. Since the recent fall of the labour share was accompanied by continued capital deepening, Hicks-neutrality does not seem to be a particularly attractive assumption. Therefore, the estimation of (17) should allow for a time trend. Initial testing indicated that a break in the trend term as in $\left(3^{\prime}\right)$ and $\left(4^{\prime}\right)$ is not significant. A linear time trend is sufficient. The regression was run both with and without a cyclical adjustment term $\zeta\left(y-y^{*}\right)$. The results are given in Table 4 .

The cointegration satistics do not contradict the joint hypothesis, embodied in (17), that firms operate both on a CES production function and on the derived labour demand curve in the long run. ${ }^{19}$ The capital-labour ratio enters with the expected positive sign whereas the coefficient of the time trend is negative, thus reconciling the nonincreasing labour share with the ongoing process of capital deepening. The RHS of (17) essentially features the capital-labour ratio, adjusted

19 Admittedly, the relatively low $\mathrm{R}^{2}$ indicates scope for improving the specification with regard to the short-run dynamics. However, our interest here is limited to the long-run validity of the first-order condition (17) for which the cointegration diagnosis testifies in the positive. 
Table 4 - Estimates of (17)

\begin{tabular}{|l|cc|}
\hline \multirow{2}{*}{} & \multicolumn{2}{|c|}{ Dependent variable: $W \cdot N / Y$} \\
\cline { 2 - 3 } & $(1)$ & $(2)$ \\
\hline Constant & 0.603 & 0.605 \\
Coeff $(k-n)$ & 0.181 & 0.174 \\
$(\lambda-\mu)$ & 0.011 & 0.011 \\
$\zeta$ & & -0.098 \\
$\mathrm{R}^{2}$ & 0.536 & 0.550 \\
$\mathrm{DW}$ & $0.360^{*}$ & 0.338 \\
$\mathrm{DF}$ & $-3.300^{*}$ & \\
$\mathrm{ADF}(4)$ & $-3.167^{* *}$ & \\
Note: $*$ **: The variables are cointegrated at the 10 and 5 per cent level, respec- \\
tively. For the data see the Appendix. \\
\hline
\end{tabular}

for a time trend $[k-n-(\lambda-\mu) t]$. In analogy to the adjusted wage gap, we refer to this variable as the adjusted capital intensity (ADJCI). The upper panel of Figure 4 plots ADJCI against the observed wage share (WS). In contrast to the unadjusted capital-labour ratio, which kept growing in absolute terms throughout the three decades under review, ADJCI fell substantially in response to the low level of investment in the 1975-1988 period. Thereby, it closely paralleled the declining wage share (WS) and the declining real wage gap (not shown in Figure 4, but depicted in Figure 1). This correlation is what the theoretical model in Section III predicts - if we bear in mind that ADJCI is the empirical counterpart of $K / N$ in Figure $3 b$.

One might object that it is improper to rely on an exogenous time trend to square an increasing capital-labour ratio with a falling wage share. However, ADJCI is closely related to the concept of capital per "effective" worker, routinely used in expositions of the Solow growth model with labour-augmenting technical progress. As the Solow model demonstrates, labour-augmenting technical progress causes a trend increase in the capital-labour ratio even in the absence of any extraneous wage pressure that might arise from labour market imperfections. Our specification differs from the scenario of the textbook model because Solow assumed $\mu=0$ and thus obtained a steady state with a constant capital-output ratio whereas Germany's capital-output ratio steadily crept upward with a pace of 1.06 per cent p.a. from 1961 to 1991 . This is why our estimates imply a higher trend growth 
Figure 4 - The Wage Share, Adjusted Capital Intensity (ADJCI) and Adjusted Relative Factor Cost (ADJRFC)
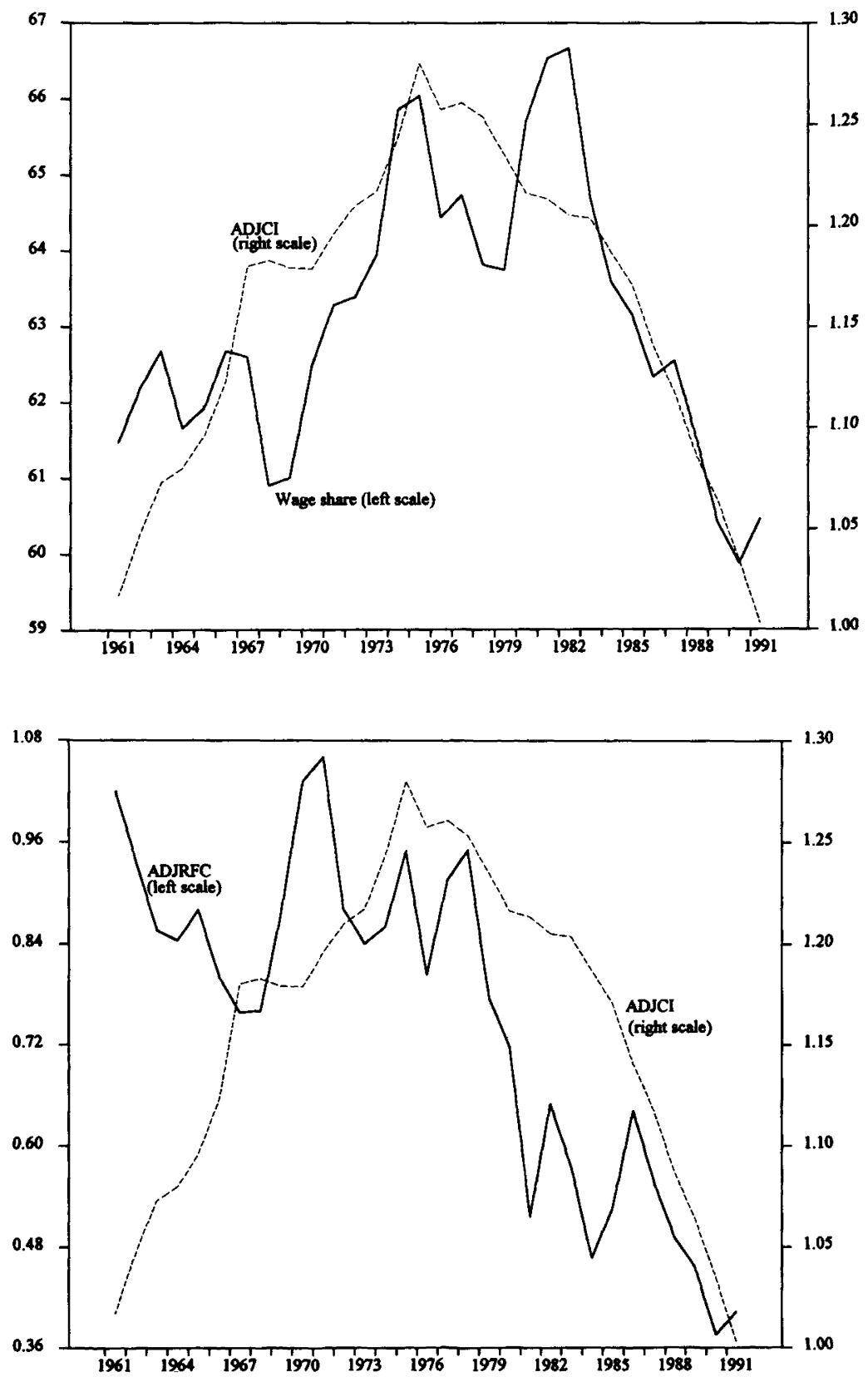
rate for the capital-labour ratio than for labour productivity (i.e. a higher value for $\lambda-\mu$ in (17) than for $\lambda$ in (3)).

While the co-movement of the wage share and the capital-labour ratio fits our story well, it does not shed light on the role of relative factor prices in causing the observed relation. We address this issue by noting that the first-order condition which defines the optimal capital stock of firms can be derived from the production function (1) in analogy to equation (3) as follows:

$$
y-k=\gamma_{0}+\sigma(u c-\mu t)+\mu t,
$$

where $u c$ is the log of the user cost of capital.

Subtracting (18) from (3), we can relate the capital-labour ratio to the factor-price ratio:

$$
k-n=\alpha_{0}-\gamma_{0}+\sigma(w-u c)+(1-\sigma)(\lambda-\mu) t
$$

or, equivalently:

$$
k-n-(\lambda-\mu) t=\alpha_{0}-\gamma_{0}+\sigma[w-u c-(\lambda-\mu) t] .
$$

The LHS of $\left(19^{\prime}\right)$ is the adjusted capital-intensity ADJCI as explained above. The term in brackets on the RHS is the factor-price ratio, adjusted in the same way. Equations (18), (19) and (19') represent steady-state relationships and do not take into account the extended adjustment process which we have modelled above. Therefore, we do not estimate these relationships. However, in order to reach a first pass judgment on the importance of relative factor prices, we have calculated the adjusted factor-price ratio $[w-u c-(\lambda-\mu) t]$, using the trend adjustment term $(\lambda-\mu) t$ as reported in Table 4 . The resulting series, termed ADJRFC, is plotted against the adjusted capital intensity (ADJCI) in the lower panel of Figure 4. As expected, the chart does not suggest an excitingly close fit of the two series, but it demonstrates that the factor-price ratio, once it is adjusted for its secular trend growth, exhibits a noticeable downward tendency accompanying the extended decline of ADJCI. Both of the shocks, which we have discussed above show up in the ADJRFC series: Around 1970, the ratio shot up as the wage explosion coincided with an accommodating stance of monetary policy, which kept the interest rate low. In contrast, the subsequent fall of ADJRFC was particularly steep in the 1978-81 period when the economy was hit by the interest rate shock. 


\section{Explaining the Slowdown of Capital Formation}

The theoretical and empirical results derived above emphasized the disinvestment process which was induced by the wage shock of the early 1970 s as well as by the real interest rate shock a decade later. In this section, we take a closer look at the causes of the slowdown of capital formation. According to (18), the equilibrium capital stock should be related to the level of output and the user cost of capital. We take into account the gradual adjustment of the capital stock by allowing for a lagged response of investment to changes in output growth and user costs. Assuming Koyck-distributed lags and following a standard approach pioneered by Bischoff [1971], we derive the following equation for the change in the capital stock: ${ }^{20}$

$$
\begin{aligned}
& \begin{array}{l}
\Delta k_{t}= \\
\quad 0.070+0.059 \Delta y_{t}-0.014 u c_{t}+0.885 \Delta k_{t-1} \\
\quad(2.459)(2.744)(-2.411)
\end{array} \\
& \text { RHO }=0.262
\end{aligned}
$$

Estimation method: OLS with correction for first-order serial correlation (Hildreth-Lu search procedure, cf. e.g. Maddala [1977, pp. $277 \mathrm{ff}$.$] ).$

Sample 1963-1991 $\overline{\mathrm{R}}^{2}: 0.961 \quad$ SEE: 0.002 LM(4): 5.847

(t-statistics in parentheses; LM(4) refers to the Lagrange Multiplier Test for serial correlation.)

Since all variables in (20) were found to be $I(0)$, the standard tests for significance are appropriate. Unlike some other studies of investment, we find a significant role for the user cost variable. ${ }^{21}$ In an attempt to identify the proximate causes of the slowing pace of capital formation, we perform two ex post simulations with (20), both for the period 1974-1991. First, we calculate a baseline path for the change

20 Note that the user cost variable appears in level form rather than as a first difference. This specification results if the lag structures of the response to changes in output and of the response to changes in the user cost are allowed to differ [Bischoff, 1971]. For other recent applications of Bischoff's approach, see Clark [1979] and Corker et al. [1989].

21 Because of data limitations, (20) was estimated with annual data for the capital stock of the aggregate economy. Of course, one could argue that only private-sector investment should be made dependent on output growth and the capital costs. On the other hand, the slump of output growth and the rise in the real interest rate importantly contributed to the perception, in the early 1980s, that the time path of Germany's public debt was unsustainable. This perception ultimately triggered the sharp cuts in public investment spending that became effective after 1982. 
Figure 5 - Actual, Predicted and Simulated Values of Capital Formation

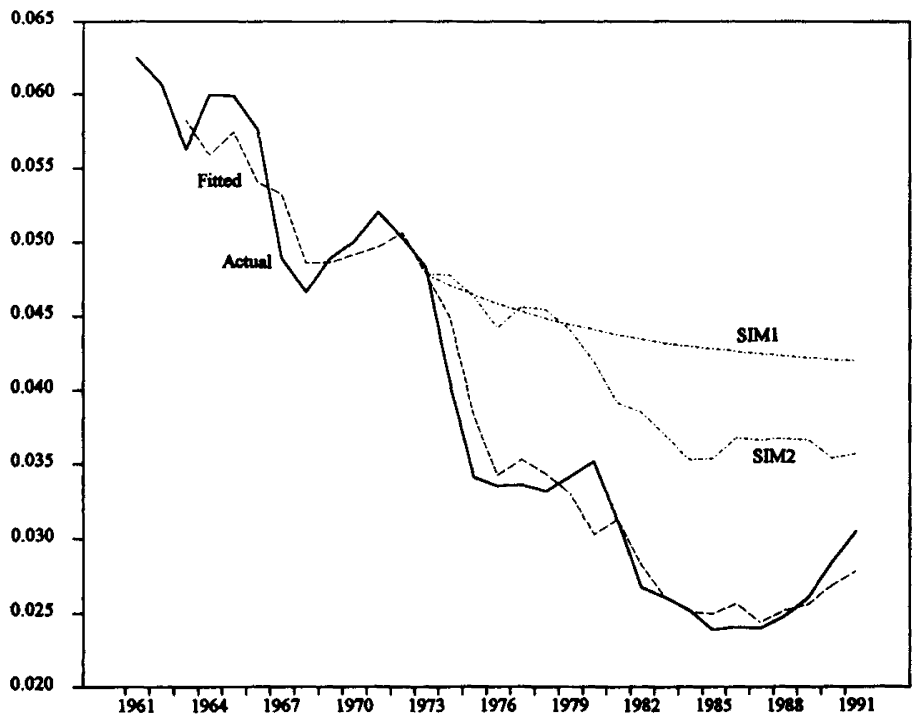

in the capital stock, assuming output growth and the user cost of capital to have remained constant at their average values of 1961-1973. In Figure 5, this baseline solution is labeled SIM1. The fact that SIM1 slopes moderately downwards indicates that the pace of capital formation up to 1973 was not sustainable even under the prevailing conditions of that period. Presumably, some slowdown of investment was inevitable after a postwar transition period in which the capital-output ratio had to be restored to its equilibrium level.

The second simulated path of $\Delta k$, labeled SIM2 in Figure 5, is based on the same output growth as SIM1, but on actual values of $u c$. Not surprisingly, SIM2 does not depart substantially from SIM1 until the run up of real interest rates around 1980. Whereas the shortfall of SIM2 as against SIM1 indicates the direct contribution of the rise in capital costs to the change in investment, the discrepancy between the fitted $\Delta k$ and SIM2 must be attributed to the slowdown of output growth. ${ }^{22}$ Output growth appears quantitatively to be the more important factor for investment than the user cost of capital, which is in

22 In 1991, the difference between the baseline solution SIM1 and SIM2 accounts for 44.5 per cent of the difference between SIM1 and the fitted values for $\Delta k$. 
line with an overwhelming body of evidence in the literature. It should be kept in mind, however, that output growth is not entirely an autonomous determinant of capital formation. Quite to the contrary, the model of Section III precisely predicts that a real interest rate shock may exert its contractionary effect on the capital stock largely via an induced contraction of aggregate output. Turning once more to Figure 3 (panel b) above, we recall that the assumed real interest rate shock lowers the capital stock from $K_{1}$ to $K_{2}$. A statistical decomposition as outlined in this section would attribute most of the change in the capital stock to the change in output - which falls from $Y_{2}$ to $Y_{3}$ and thus warrants a lower capital stock, given the initial capitallabour ratio. The change in the user cost of capital, though it is the ultimate source of the entire disinvestment process, would not be credited but for the minor movement to the new equilibrium capitallabour ratio along the $Y_{3}$ isoquant. Thus, a statistical decomposition based on an equation such as (20) can at best provide a lower bound for the fraction of the investment slowdown that is in fact caused by the sustained rise in the real interest rate.

\section{Concluding Remarks}

Unemployment in Germany, as elsewhere in Europe, has increased dramatically between the early 1970 s and the late 1980 s. In the 1970 s, the mainstream view blamed excessive wage pressure. This view made heavy use of the real wage gap measures which indicated that real wages were running ahead of (trend) productivity. In the 1980s, when unemployment rose still higher while the real wage gap declined rapidly, the mainstream view was that excessive wage pressure could no longer be blamed [see Gordon, 1988; Paqué, 1990]. Our analysis in this paper has led us to two broad conclusions: First, the real wage gap, as usually measured, is of little use as an indicator of excessive wage pressure. Second, whereas the mainstream view of the 1970s nevertheless seems to be correct, the mainstream view of the 1980 s is more dubious.

The basic argument underlying our first conclusion is very simple: Since the real wage is an endogenous variable of the macroeconomic system, jointly determined by wage-setting and labour demand behaviour, it cannot be expected to be related to employment in any stable way. Depending on whether exogenous shocks affect the labour market through the wage-setting schedule or through the labour demand schedule, the real wage and the unemployment rate will move 
together or in opposite directions. Our explanation of why they moved in opposite directions after the mid-1970s points to the role of the slowing capital formation.

The notion that European unemployment may be related to insufficient investment is not uncontroversial. It is dismissed out of hand by Gordon [1988, p. 278] who cited the 87.6 per cent increase in Europe's capital-labour ratio from 1972 to 1986 as evidence of the contrary (for Germany, the figure is 78.6 per cent). However, once the capitallabour ratio is adjusted for its trend, which would normally be expected to be increasing in a growing economy, we find a rather steep decline after 1975 (Figure $4 \mathrm{a}$, above). If the elasticity of substitution between capital and labour lies below unity, as most estimates including our own imply, any reduction of the (trend-adjusted) capitallabour ratio must lower the wage share in national income and the (adjusted) real wage gap, which is what actually happened.

The pace of capital accumulation also plays a significant role in the theoretical framework underlying the "European Unemployment Project" described in Drèze and Bean [1990a]. In fact, the German contribution to the project [Entorf et al., 1990] presents empirical results which give strong support to the notion that a lack of productive capacity limited employment growth in Germany. To be sure, whereas their approach emphasizes rationing phenomena stemming from demand and capacity constraints, we ignore such disequilibrium mechanisms and instead adopt an equilibrium perspective in which the capital stock enters as a determinant of labour market equilibrium. Whenever the wage-setting process exhibits real wage resistance, as equation (12) of our model assumes, a downward shift of the labour demand schedule due to a fall in the (trend-adjusted) capital-labour ratio inevitably translates into rising unemployment.

Since we did not estimate a wage-setting equation, we cannot say how much additional unemployment is in fact explained by this mechanism. What we can say, however, is this: The disappearance of the German real wage gap, though widely interpreted as evidence of "wage moderation", is perfectly consistent with the view that the persistent high unemployment of the 1980s results from a failure of the wage-setting process to adjust to a continued slowdown of feasible real wage growth.

A referee raised the question whether the strong investment performance of West Germany in 1990/91 and the concomitant moderate rise in our real wage gap measure might indicate a turnaround in the trend of the preceding decade. At the time of writing, it is too early to 
tell - all the more so as the 1990/91 unification boom was followed by a deep recession. However, the events surrounding the German unification demonstrate the force of our argument in another, sad way. The integration of a seriously undercapitalized economy meant an abrupt fall in the capital-labour ratio for the Federal Republic of Germany as a whole. But wage-setters, striving for a quick elimination of the East-West wage differential showed very little willingness to take this fact into account. Thereby, they caused a new and presumably persistent unemployment problem affecting eastern Germany, in particular.

\section{Data Appendix}

All data are taken from Vierteljährliche Volkswirtschaftliche Gesamtrechnung des Deutschen Instituts für Wirtschaftsforschung (DIW), Berlin, except

- the nominal interest rate, which is the "Umlaufrendite festverzinslicher Wertpapiere" (Monatsberichte der Deutschen Bundesbank, various issues),

- the capital stock, which is due to Lüdeke [Lüdeke et al., 1989, p. 11].

- the user cost of capital, which were calculated according to Jerger [1993, pp. 197f.] using input series kindly provided by Lüdeke.

The capital stock is broadly defined, encompassing capital goods purchased by both the private and the public sector. Accordingly, the user cost of capital is calculated so as to cover the broad aggregate of gross fixed investment, taking into account the different real prices and depreciation rates of different investment categories.

In the measures of $y-n$ and $k-n$ (estimates of $\left(3^{\prime}\right)$ and (17)) $y$ refers to (the log of) gross national product and $n$ to hours worked, respectively.

The wage share $(W N / Y)$ (estimates of $\left(4^{\prime}\right)$ and (17)) is adjusted for changes in the share of self employment (base period 1960:1) in the usual manner. See, for example, Sachverständigenrat [1992, p. 261].

Output at normal capacity utilization, $Y^{*}$, has been calculated according to Sachverständigenrat [1992, p. 259].

The seasonal adjustment has been done with EZ-X11, Version 2.00 of Doan Associates, Evanston, IL (USA), which is a version of Census $\mathrm{X}-11$ of the US Bureau of Census. 


\section{References}

Bean, Charles, "Capital Shortages and Persistent Unemployment". Economic Policy, Vol. 8, 1989, pp. 12-53.

Bischoff, Charles, "The Effect of Alternative Lag Distributions". In: G. Fromm (Ed.), Tax Incentives and Capital Spending. Washington, D.C., 1971, pp. 61-125.

Blanchard, Olivier, "Unemployment: Getting the Questions Right - and Some of the Answers". In: J. Drèze, Ch. Bean (Eds.), Europe's Unemployment Problem. Cambridge, Mass., 1990, pp. 66-89.

-, Stanley Fischer, Lectures on Macroeconomics. Cambridge, Mass., 1989.

Bruno, Michael, “Aggregate Supply and Demand Factors in OECD Unemployment: An Update". Economica, Vol. 53, Supplement, 1986, pp. 35-52.

-, Jeffrey Sachs, The Economics of Worldwide Stagflation. Cambridge, Mass., 1985.

Burda, Michael, "Is There a Capital Shortage in Europe?". Weltwirtschaftliches Archiv, Vol. 124, 1988, pp. 38-57.

Clark, Peter, "Investment in the 1970s: Theory, Performance, and Prediction". Brookings Papers on Economic Activity, Vol. 1, 1979, pp. 73-113.

Corker, Robert, Owen Evans, Lloyd Kenward, "Tax Policy and Business Investment in the United States: Evidence from the 1980s”. IMF Staff Papers, Vol. 36, 1989, pp. 31-62.

Dickey, David, Wayne Fuller, "Distribution of the Estimators for Autoregressive Time Series With a Unit Root". Journal of the American Statistical Association, Vol. 74, 1979, pp. 427-431.

-,-, "The Likelihood Ratio Statistic for Autoregressive Time Series With a Unit Root”. Econometrica, Vol. 49, 1981, pp. 1057-1072.

Drèze, Jacques, Charles Bean (Eds.) [1990a], Europe's Unemployment Problem. Cambridge, Mass., 1990.

-, - [1990b], "Europe's Unemployment Problem: Introduction and Synthesis". In: J. Drèze and Ch. Bean (Eds.), Europe's Unemployment Problem. Cambridge, Mass., 1990, pp. 1-65.

Engle, Robert, Clive Granger, "Co-Integration and Error Correction: Representation, Estimation, and Testing”. Econometrica, Vol. 55, 1987, pp. 251-276.

Entorf, Horst, Wolfgang Franz, Heinz König, Werner Smolny, "The Development of German Employment and Unemployment: Estimation and Simulation of a Small Macro Model"'. In: J. Drèze, Ch. Bean (Eds.), Europe's Unemployment Problem. Cambridge, Mass., 1990, pp. 239-287.

Fitoussi, Jean-Paul, Edmund Phelps, The Slump in Europe. Oxford, 1988.

Franz, Wolfgang, "Hysteresis, Persistence, and the NAIRU: An Empirical Analysis for the Federal Republic of Germany". In: R. Layard, L. Calmfors (Eds.), The Fight Against Unemployment. Cambridge, 1987, pp. 91-122.

Gordon, Robert, "Back to the Future: European Unemployment Today Viewed from America in 1939". Brookings Papers on Economic Activity, Vol. 1, 1988, pp. 271-304.

Hellwig, Martin, Manfred Neumann, "Economic Policy in Germany: Was There a Turnaround?". Economic Policy, Vol. 5, 1987, pp. 105-145. 
Jerger, Jürgen, Beschäftigung und Kapitalbildung. Freiburg, 1993.

Kmenta, Jan, “An Estimation of the CES Production Function". International Economic Review, Vol. 8, 1967, pp. 180-189.

Krugman, Paul, "Slow Growth in Europe: Conceptual Issues". In: R. Lawrence, Ch. Schultze (Eds.), Barriers to European Growth. Washington, D.C., 1987, pp. 48-76.

Landmann, Oliver, Jürgen Jerger, "Domestic and Foreign Shocks to Employment and Capital Accumulation in Germany”. In: H. Frisch, A. Wörgötter (Eds.), Open-Economy Macroeconomics. Houndmills, 1993, pp. 186-202.

Lawrence, Robert, Charles Schultze (Eds.), Barriers to European Growth. Washington, D.C., 1987.

Layard, Richard, Charles Bean, "Why Does Unemployment Persist?". The Scandinavian Journal of Economics, Vol. 91, 1989, pp. 371-396.

Lindbeck, Assar, "Macroeconomic Theory and the Labor Market". European Economic Review, Vol. 36, 1992, pp. 209-235.

Lüdeke, Dietrich, Wolfgang Hummel, Thomas Rüdel, Das Freiburger Modell. Heidelberg, 1989.

Maddala, G.S., Econometrics. New York, 1977.

McCallum, John, "Wage Gaps, Factor Shares and Real Wages". The Scandinavian Journal of Economics, Vol. 87, 1985, pp. 436-459.

OECD, Economic Surveys - Germany, 1987/88. Paris, 1988.

Paqué, Karl-Heinz, Unemployment in West Germany - A Survey of Explanations and Policy Options. Kiel Working Paper, No. 407. Kiel, 1990.

Phillips, Peter, "Understanding Spurious Regressions in Econometrics". Journal of Econometrics, Vol. 33, 1986, pp. 311-340.

-, "Time Series Regressions With A Unit Root". Econometrica, Vol. 55, 1987, pp. 277 301.

-, Pierre Perron, "Testing for a Unit Root in Time Series Regressions". Biometrika, Vol. 75, 1988, pp. 335-346.

Sachs, Jeffrey, "Real Wages and Unemployment in the OECD Countries". Brookings Papers on Economic Activity, Vol. 1, 1983, pp. 255-289.

Sachverständigenrat zur Begutachtung der gesamtwirtschaftlichen Entwicklung, Für Wachstumsorientierung - Gegen lähmenden Verteilungsstreit. Stuttgart, 1992.

Sargan, J. Denis, Alok Bhargava, "Testing Residuals from Least Squares Regressions for Being Generated by the Gaussian Random Walk”. Econometrica, Vol. 51, 1983, pp. 153-174.

Schultze, Charles, "Real Wages, Real Wage Aspirations, and Unemployment in Europe". In: R. Lawrence, Ch. Schultze (Eds.), Barriers to European Growth. Washington, D.C., 1987, pp. 230-302.

Stock, James, “Asymptotic Properties of Least Squares Estimators of Co-Integrating Vectors". Econometrica, Vol. 55, 1987, pp. 1035-1056.

-, Mark Watson, "Testing for Common Trends". Journal of the American Statistical Association, Vol. 83, 1988, pp. 1097-1107. 
A bstract: Unemployment and the Real Wage Gap: A Reappraisal of the German Experience. - The major European economies experienced a rise in unemployment since the late $1970 \mathrm{~s}$. At the same time, the real wage gap, a widely used measure of wage pressure, declined. This paper develops an analytical framework that relates the two phenomena. Particular emphasis is placed on the interaction of capital accumulation, wage setting and labour demand. The model is applied to the particular case of Germany and found to be consistent with the observed behaviour of wages, investment, output and employment.

Zusammenfassung: Arbeitslosigkeit und die Reallohnlücke. Eine Überprüfung der deutschen Erfahrung. - Die wichtigsten europäischen Volkswirtschaften erlebten seit den späten siebziger Jahren einen Anstieg der Arbeitslosigkeit. Gleichzeitig ging die Reallohnlücke, die weithin als $\mathrm{Maß}$ für den Lohndruck benutzt wird, zurück. Die Verfasser entwickeln einen analytischen Rahmen, der diese beiden Phänomene zueinander in Beziehung setzt. Besonderen Wert legen sie auf das Zusammenwirken von Kapitalbildung, Lohnfestsetzung und Nachfrage nach Arbeit. Sie wenden das Modell auf den Fall Deutschland an und zeigen, daß es mit dem beobachteten Verlauf von Löhnen, Investitionen, Produktion und Beschäftigung konsistent ist. 